Teknik, 38 (1), 2017, 1-5

\title{
Kajian Perilaku Dinamik Struktur Jembatan Penyeberangan Orang Dua Lantai Akibat Beban Manusia Yang Bergerak
}

\author{
Himawan Indarto*, Bambang Pudjianto, Iham Nurhuda
}

\author{
Departemen Teknik Sipil, Fakultas Teknik, Universitas Diponegoro, \\ Jl. Prof. Soedarto, SH, Kampus Undip Tembalang, Semarang, Indonesia 50275
}

\begin{abstract}
Abstrak
Jembatan Penyeberangan Orang (JPO) dengan bentang panjang pada lantai bertingkat mulai banyak dibangun di kota-kota besar di Indonesia. JPO dibangun sebagai sarana penghubung dari satu bangunan ke bangunan lainnya sekaligus berfungsi sebagai jembatan penyeberangan bagi lalu lintas yang berada di bawahnya. Bentuk strukturnya yang langsing membawa konsekuensi struktur JPO rentan terhadap masalah getaran. Munculnya getaran pada struktur JPO pada saat orang melewatinya menyebabkan ketidaknyamanan bagi pengguna jalan di bawahnya. Penelitian ini bertujuan untuk mengkaji perilaku dinamik struktur JPO kemudian membuat kriteria desain yang harus dipenuhi oleh struktur JPO demi mendapatkan perencanaan yang memenuhi syarat kekakuan. Dari hasil penelitian diketahui bahwa, beban pejalan kaki yang bersifat dinamik pada struktur JPO dua lantai menyebabkan deformasi struktur 1,55 kali lebih besar daripada deformasi yang didapat dari analisis statik. Ini harus dipertimbangkan dalam mendesain struktur JPO. Jika factor ini dipenuhi maka masalah yang muncul akibat getaran ketika JPO digunakan dapat dihindari.
\end{abstract}

Kata kunci: Jembatan Penyeberangan Orang; beban dinamik; deformasi; frekuensi getar

\begin{abstract}
[Title: Structure Dynamics Analysis on Multi Levels Pedestrian Bridge due to human dynamic movement] A long span and Multi Levels Pedestrian Bridge (MLPB) have been built at most of metropolitan city in Indonesia. The pedestrian bridge is a connector of one building to the other one. At the same time, a pedestrian bridge also provides a traffic facility of the activities below the structures. A slender structure form of pedestrian bridge emerges consequences to the vibration effect. Hence, it will be inconvenient for people to pass through. This research aimed to analyze the structure dynamics of MLPB and to determine design criteria for the convenient MLPB which fulfils stiffness and strength condition. The results revealed that dynamic analysis have an amplification factor of deformation up to 1.55 greater than static analysis. This should be considered in designing $M L P B$. Once this factor is fulfilled, the vibration effects can be avoided during the service.
\end{abstract}

Keywords: pedestrian bridge; dynamic load; natural frequency

\section{Pendahuluan}

Jembatan Penyeberangan Orang (JPO) saat ini mulai banyak dibangun di pusat kota-kota besar di Indonesia. Pada umumnya JPO dibangun sebagai sarana penghubung dari satu bangunan ke bangunan lainnya, sekaligus berfungsi sebagai jembatan penyeberangan bagi lalu lintas yang berada di bawahnya.

JPO dapat berupa jembatan yang berfungsi sebagai jembatan penyeberang orang yang melintang diatas jalan raya, dan jembatan yang dibangun untuk menghubungkan dua bangunan gedung, atau yang sering disebut sebagai sky bridge. Gambar 1 dan Gambar 2 menampilkan JPO satu dan dua lantai.

\footnotetext{
${ }^{*}$ Penulis Korespondensi.

E-mail: himawan.indarto@gmail.com
}

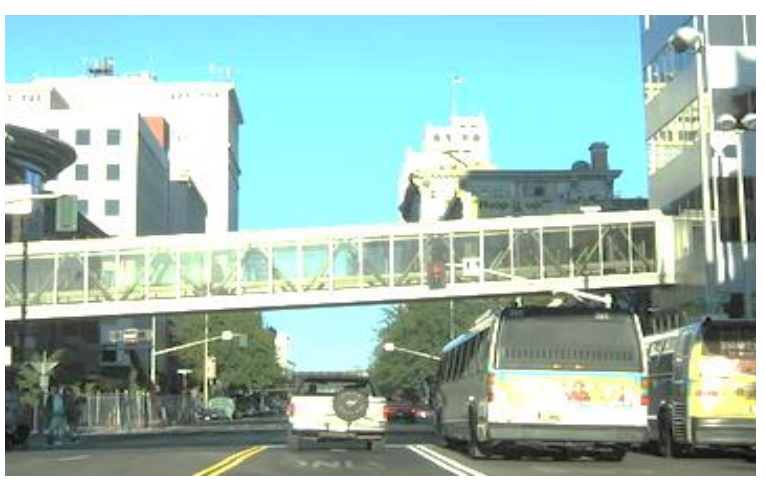

Gambar 1. JPO satu lantai di kawasan perkotaan 


\section{Teknik, 38 (1), 2017, 2}

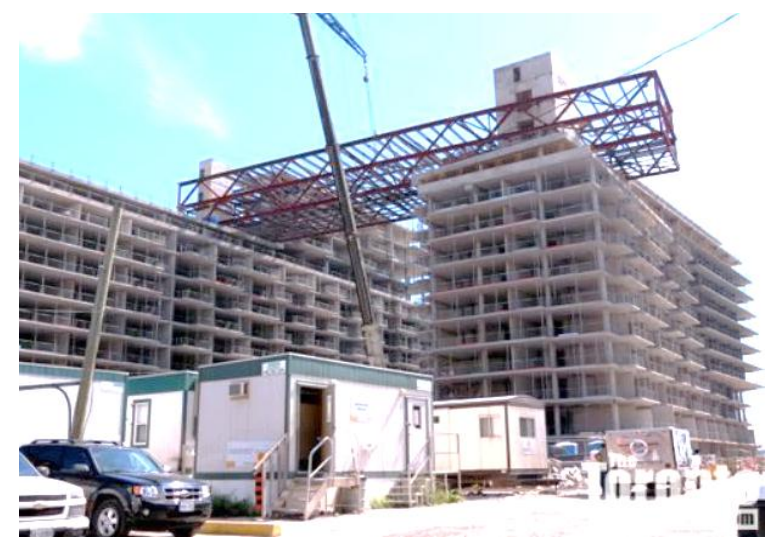

Gambar 2. JPO dua lantai diatas gedung (Sky Bridge) sedang dalam tahapan pembangunan

Karena merupakan bagian dari bangunan yang berada di pusat-pusat keramaian kota, maka bentuk arsitektur dan estetika dari struktur JPO merupakan kriteria utama yang harus dipenuhi sebagai persyaratan desain. Struktur JPO pada umumnya dirancang dengan bentuk struktur yang langsing, dengan menggunakan material baja. Hal ini berbeda dengan jembatan-jembatan lainnya, misalnya Jembatan Jalan Raya (JJR), yang pada umumnya dirancang dengan bentuk yang lebih kaku dan masif.

Bentuk struktur yang langsing membawa konsekuensi, bahwa struktur JPO rentan terhadap masalah getaran. Masalah munculnya getaran pada elemen-elemen struktur JPO pada saat orang melewati jembatan, akan menyebabkan ketidaknyamanan bagi pengguna jalan.

Getaran yang muncul pada JPO dapat diakibatkan oleh karena frekuensi getar alami dari struktur JPO yang terlalu besar, atau terjadinya resonansi yang diakibatkan karena frekuensi getar beban yang melewati JPO mendekati frekuensi getar alami dari struktur. Frekuensi getar alami yang besar dari struktur JPO diakibatkan karena bentuk struktur yang langsing, hal ini dijumpai pada struktur JPO dengan bentang yang panjang. Untuk mencegah timbulnya getaran pada saat difungsikannya JPO, maka kedua hal tersebut diatas, harus diperhatikan pada saat proses desain dilakukan.

Untuk memperhitungkan pengaruh beban-beban yang bersifat dinamik pada struktur jembatan, dilakukan dengan cara mengalikan beban-beban statik dengan suatu faktor pembesaran dinamik, yang besarnya sudah dicantumkan di dalam peraturan. Beberapa hal yang menyangkut permasalahan beban dinamik yang dapat mengakibatkan terjadi resonansi pada struktur, belum dicantumkan pada standar-standar ini

Ditinjau dari segi pembebanan, JPO berbeda dengan JJR. Struktur JPO harus diperhitungkan terhadap pengaruh beban akibat manusia yang bergerak diatasnya, yang dapat menyebabkan pengaruh vertikal dan horisontal pada struktur. Pengaruh akibat manusia yang bergerak merupakan beban dinamik yang bekerja pada struktur JPO, belum dijelaskan pada standar-standar perencanaan yang ada di Indonesia.

Meskipun beban akibat manusia pada JPO adalah kecil jika dibandingkan dengan beban kendaraan pada JJR, tapi jika tidak dilakukan evaluasi desain dengan baik, dapat mengakibatkan kegagalan struktur. Ini disebabkan beban manusia yang bergerak dapat menghasilkan getaran yang berlebihan pada struktur jika terjadi resonansi.

Penelitian ini bertujuan untuk mengkaji perilaku dinamik dari struktur JPO kemudian membuat kriteria desain yang memenuhi syarat kekakuan, sehingga dapat meminimisasi terjadinya getaran pada saat JPO digunakan. Perilaku dinamik dari struktur JPO yang akan dikaji adalah frekuensi getar dan respon dinamik dari struktur JPO akibat pengaruh beban beban manusia yang bergerak.

\section{Metode Penelitian}

Untuk dapat mengetahui besarnya frekuensi alami (natural frequency) dan ragam getar (mode shape) dari struktur JPO, dilakukan analisis dinamik struktur dengan menggunakan Metode Analisis Ragam (Modal Analysis). Frekuensi alami struktur adalah frekuensi dari struktur yang secara alami cenderung untuk bergetar jika ada gangguan pada struktur (Wahyuni, 2012), sedangkan ragam getar struktur adalah, bentuk deformasi struktur pada frekuensi yang spesifik.

Nilai frekuensi alami dari struktur dapat digunakan sebagai acuan, untuk mengetahui apakah struktur akan mengalami resonansi atau tidak, jika mendapat pengaruh pembebanan dinamik. Suatu struktur akan mengalami resonansi jika nilai frekuensi dari beban dinamik yang bekerja pada struktur mendekati atau sama dengan frekuensi alami struktur.

Berbeda dengan beban kendaraan yang bekerja pada JJR, pada JPO beban yang dominan bekerja pada struktur adalah beban akibat pergerakan manusia yang lewat diatasnya. Pada perencanaan struktur lainnya, biasanya beban manusia dikategorikan sebagai beban hidup yang besarnya sudah ditentukan di dalam standar pembebanan yang berlaku. Besarnya beban hidup pada perencanaan struktur gedung, biasanya dianggap sebagai beban merata tidak bergerak, yang dapat ditempatkan di sembarang tempat. Sebagai contoh, di dalam standar pembebanan yang berlaku di Indonesia, beban hidup rencana pada gedung parkir, besarnya ditentukan sebesar $400 \mathrm{~kg} / \mathrm{m}^{2}$, sedangkan beban hidup pada trotoar jembatan ditentukan sebesar $500 \mathrm{~kg} / \mathrm{m}^{2}$.

\section{Hasil dan Pembahasan}

Menurut Brownjohn dan Pavic (2007), aktivitas manusia yang melakukan jalan bersama, meloncat, atau belari dengan kecepatan tertentu, akan mengakibatkan getaran pada struktur. Beban pada struktur akibat aktivitas manusia tidak bersifat statis melainkan dinamis karena 


\section{Teknik, 38 (1), 2017, 3}

menghasilkan reaksi vertikal dan horisontal yang berubah-ubah terhadap waktu.

Untuk dapat melakukan analisis atau kajian dinamik dari struktur JPO, diperlukan model pembebanan dinamik yang diakibatkan oleh pergerakan manusia. Untuk memeriksa perilaku dinamik dari struktur JPO, beban yang harus diperhitungkan adalah beban manusia berjalan.

Untuk mengetahui besarnya beban dinamik akibat pergerakan manusia, Brownjohn dan Pavic (2007) telah melakukan pengukuran beban dinamik yang diakibatkan oleh orang yang berjalan. Selama orang berjalan, akan menimbulkan beban dinamik pada tiga arah, yaitu: arah vertikal, horisontal-lateral, dan horisontal-longitudinal.

Hasil pengukuran yang dilakukan Brownjohn dan Pavic menunjukkan bahwa, frekuensi alami dari kekuatan pejalan kaki arah lateral, dua kali lebih rendah dari arah vertikal dan longitudinal. Dari hasil pengukuran yang telah dilakukan, didapatkan kurva riwayat waktu yang menjelaskan hubungan antara periode berjalan orang dengan beban dinamis yang ditimbulkannya dalam arah vertikal, lateral, dan longitudinal seperti diperlihatkan pada Gambar 3.

Untuk mengetahui perilaku dinamik dari struktur JPO 2 Lantai akibat pergerakan manusia, dilakukan simulasi analisis riwayat waktu (time history analysis). Periode getar dan ragam getar dari struktur JPO 2 Lantai dihitung dengan analisis dinamik ragam (modal analysis) menggunakan software SAP2000.
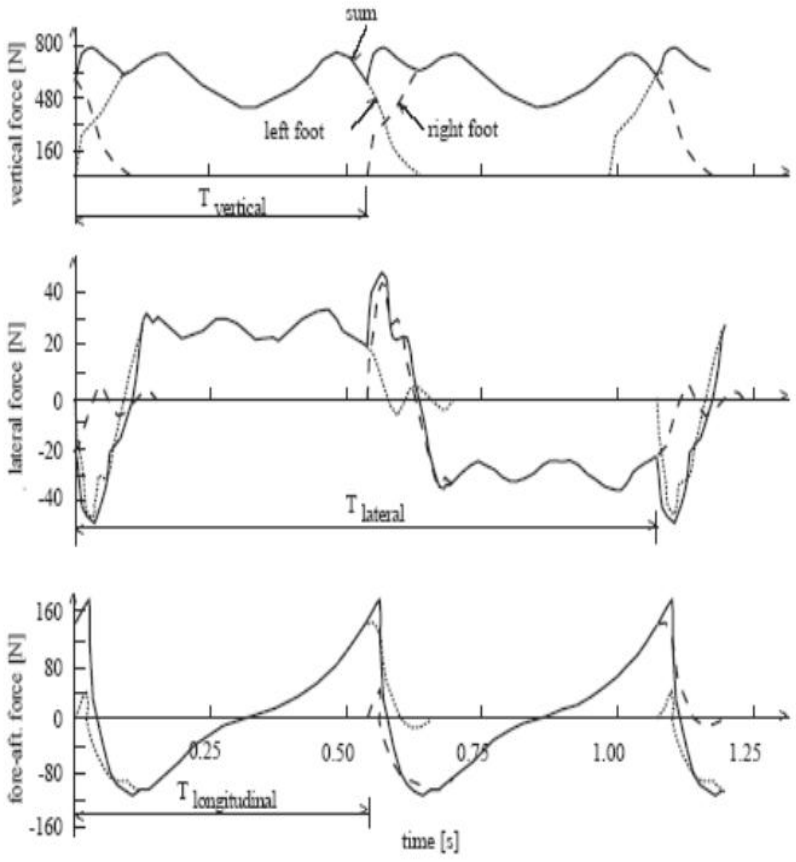

Gambar 3. Kurva Riwayat Waktu Periode berjalan orang dan beban dinamik yang ditimbulkan pada arah vertikal, lateral, dan longitudinal (Brownjohn dan Pavic, 2007)
Gambar 4 dan Gambar 5 menunjukkan fungsi dari beban dinamik dalam arah vertikal, lateral, dan longitudinal, yang akan digunakan untuk melakukan analisis pada model struktur JPO dua lantai.

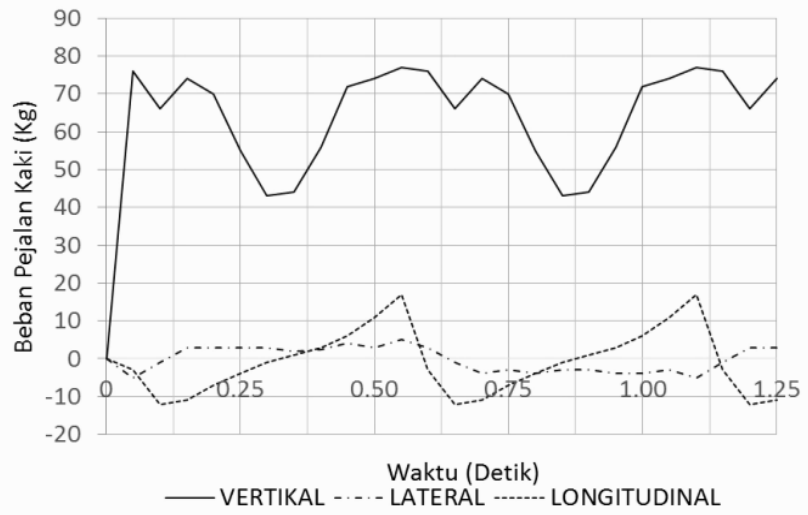

Gambar 4. Fungsi beban dinamik akibat beban orang yang bergerak hasil pengukuran Brownjohn dan Pavic (2007)

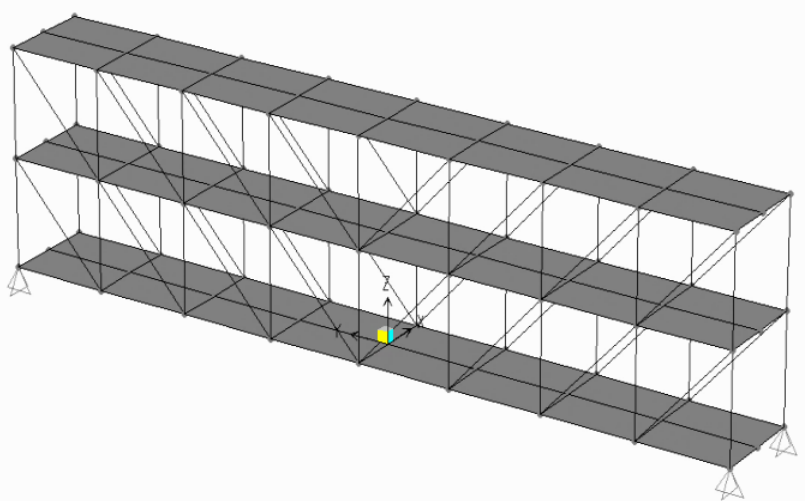

Gambar 5. Model struktur JPO dua Lantai dengan elemen Frame profil baja IWF dan elemen Shell pelat beton

Konfigurasi dari struktur JPO dua lantai yang akan dianalisis merupakan jembatan penyeberangan dari struktur baja dengan lantai dari pelat beton tebal $10 \mathrm{~cm}$. Panjang bentang JPO yang akan dianalisis adalah 24 meter, dengan lebar jembatan 3 meter, dan tinggi jembatan 6,0 meter (2 tingkat).

Struktur rangka JPO menggunakan profil baja IWF-150.150.10.7, dengan mutu baja adalah: tegangan leleh $240 \mathrm{MPa}$ dan tegangan tarik $400 \mathrm{MPa}$, serta modulus elastisitas baja: $\mathrm{E}=2100000 \mathrm{~kg} / \mathrm{cm}^{2}$.

Untuk analisis struktur dari JPO 2 Lantai, digunakan model struktur 3 dimensi. Profil baja IWF dimodelkan sebagai elemen Frame, dan lantai beton dimodelkan sebagai elemen Shell. Struktur JPO diasumsikan tertumpu pada bangunan gedung di kedua ujungnya.

Sesuai standard pembebanan yang berlaku di Indonesia, pada JPO 2 Lantai diperhitungkan beban hidup 


\section{Teknik, 38 (1), 2017, 4}

sebesar $500 \mathrm{~kg} / \mathrm{m}^{2}$. Beban hidup yang diperhitungkan di dalam analisis, merupakan beban hidup dinamik dengan fungsi beban seperti yang ditunjukkan hasil pengukuran oleh Brownjohn dan Pavic (2007).

Dari hasil analisis dinamik, didapatkan frekuensi getar struktur JPO 2 Lantai kearah vertikal = 8,67 Hertz, dan kearah horisontal $=3,64$ Hertz. Dengan mengacu pada Standard BSI (2005), dapat disimpulkan bahwa struktur JPO 2 Lantai yang terbuat dari konstruksi baja ini, aman terhadap pengaruh getaran. Hal ini disebabkan karena frekuensi getar JPO 2 Lantai kearah vertikal > 5,0 Hertz, dan frekuensi getar kearah horisontal > 1,5 Hertz.

Dari hasil analisis dinamik riwayat waktu struktur JPO 2 Lantai terhadap beban pejalan kaki, didapatkan nilai-nilai yang maksimum dari lendutan/deformasi vertikal, gaya batang elemen struktur, dan reaksi tumpuan arah vertikal dari struktur, seperti dicantumkan pada Tabel 1.

Tabel 1. Lendutan, Gaya Batang, dan Reaksi Tumpuan Arah Vertikal pada Struktur JPO 2 Lantai

\begin{tabular}{|c|c|c|c|}
\hline \multirow[b]{2}{*}{$\begin{array}{c}\text { Tipe } \\
\text { Analisis }\end{array}$} & \multicolumn{3}{|c|}{ Struktur JPO 2 Lantai } \\
\hline & Lendutan & $\begin{array}{c}\text { Gaya } \\
\text { Batang }\end{array}$ & $\begin{array}{c}\text { Reaksi } \\
\text { Tumpuan }\end{array}$ \\
\hline Statik & $4,48 \mathrm{~mm}$ & 10,4 ton & 20,25 ton \\
\hline Dinamik & $6,95 \mathrm{~mm}$ & 14,6 ton & 23,35 ton \\
\hline
\end{tabular}

Dari hasil analisis diketahui bahwa, terdapat pebedaan yang cukup besar antara analisis statik dan analisis dinamik. Lendutan yang terjadi pada struktur JPO hasil analisis dinamik lebih besar 1,55 kali dibandingkan hasil analisis statik, sedangkan gaya batang pada elemen struktur JPO hasil analisis dinamik lebih besar 1,40 kali dibandingkan hasil analisis statik (Tabel 2).

Gambar 6, 7, dan 8, menunjukkan perbandingan hasil analisis dinamik dan analisis statik dari lendutan, reaksi tumpuan, dan gaya batang dari struktur JPO.

Tabel 2. Nilai Perbandingan (R) antara Analisis Dinamik dan Analisis Statik dari struktur JPO 2 Lantai

\begin{tabular}{lccc}
\hline \multicolumn{1}{c}{ Keterangan } & $\begin{array}{c}\text { Analisis } \\
\text { Dinamik }\end{array}$ & $\begin{array}{c}\text { Analisis } \\
\text { Statik }\end{array}$ & R \\
\hline Lendutan & $6,95 \mathrm{~mm}$ & $4,48 \mathrm{~mm}$ & 1,55 \\
Gaya Batang & 14,60 ton & 10,40 ton & 1,40 \\
Reaksi Tumpuan & 23,35 ton & 20,25 ton & 1,15 \\
\hline
\end{tabular}

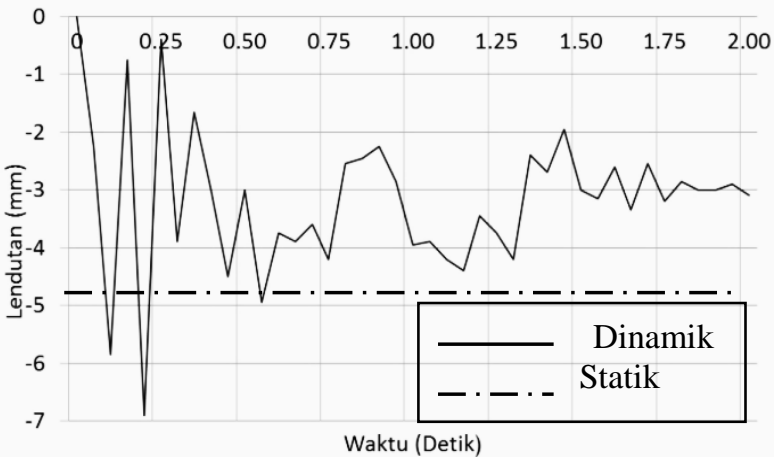

Gambar 6. Lendutan di tengah bentang JPO 2 Lantai akibat beban statik dan beban dinamik pejalan kaki

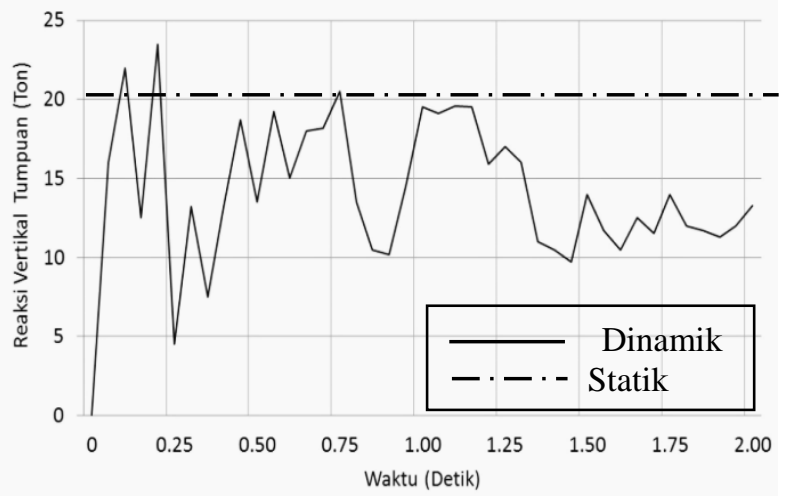

Gambar 7. Reaksi tumpuan arah vertikal pada struktur JPO 2 Lantai akibat beban statik dan beban dinamik pejalan kaki

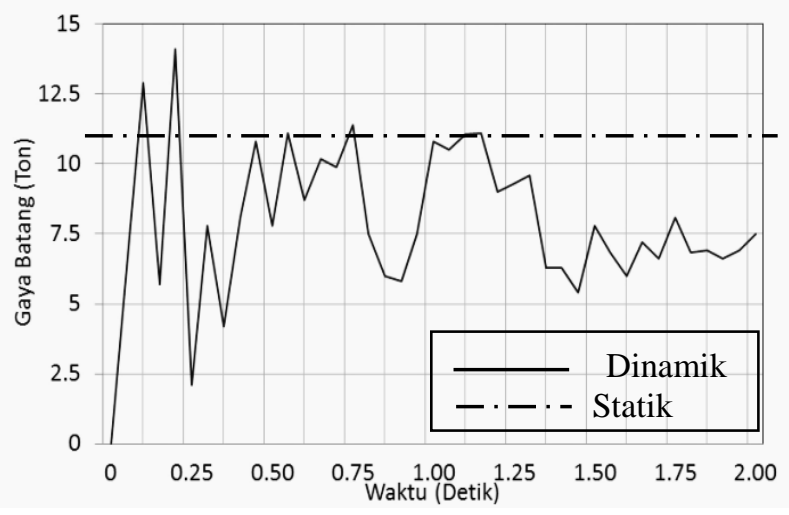

Gambar 8. Gaya batang elemen struktur JPO 2 Lantai akibat beban statik dan beban dinamik pejalan kaki.

Dari hasil perhitungan frekuensi getar struktur JPO diketahui frekuensi getar struktur arah horisontal $=3,64$ hertz $>1,5$ hertz, dan frekuensi getar struktur arah vertikal $=8,67$ hertz $>5,0$ hertz. Dengan mengacu pada Standard BSI (2005), dapat disimpulkan bahwa struktur JPO yang terbuat dari rangka baja dengan pelat beton, cukup aman terhadap pengaruh getaran yang diakibatkan oleh beban manusia bergerak yang diatasnya. 


\section{Teknik, 38 (1), 2017, 5}

Dari hasil analisis dinamik riwayat waktu, dapat disimpulkan bahwa pengaruh beban dinamik dari orang yang bergerak di atas struktur JPO, akan menyebabkan deformasi, gaya batang, dan reaksi tumpuan menjadi lebih besar dibandingkan dengan cara analisis secara statik. Nilai perbandingan (R) antara analisis dinamik dan analisis statik untuk lendutan adalah 1,55 , nilai $\mathrm{R}$ untuk gaya batang adalah 1,40 , dan nilai $\mathrm{R}$ untuk reaksi tumpuan adalah 1,15 .

\section{Kesimpulan}

Kajian perilaku dinamis struktur JPO dua lantai terhadap orang berjalan sudah dilakukan. Perencana struktur JPO perlu memperhitungkan pengaruh beban pejalan kaki yang bersifat dinamik yang mempunyai tiga komponen beban ke arah vertikal, longitudinal, dan lateral. Jika pada perencanaan struktur JPO beban pejalan kaki diasumsikan bersifat statik dan hanya diperhitungkan mempunyai satu komponen beban ke arah vertikal, maka hasil dari analisis struktur yang berupa deformasi, gaya dalam elemen (momen, gaya geser, gaya normal, dan torsi), serta reaksi tumpuan, perlu dikalikan dengan faktor pembesaran dinamik sebesar 1,55.

\section{Daftar Pustaka}

Badan Standarisasi Nasional. (2008). Standar Perencanaan Ketahanan Gempa Untuk Jembatan (SNI 03-2833-2008). Diakses dari http://www.pu.go.id/uploads/services/service20130 717121434.pdf.
--, (2005). Standar Pembebanan Untuk Jembatan (RSNI T-02-2005). Diakses dari http://jdih.bpk.go.id/wpcontent/uploads/2011/03/SNI-T-02-2005tm.pdf.

British Standart Institution (BSI). (2005) Human Response To Vibration - Measuring Instrumentations BS EN ISO 8041 : 2005. London: BSI.

Brownjohn, J.M.W. dan Pavic, A. (2007) Experimental Method for Estimating Modal Mass in Foot Bridges Using Human Induced Dynamic Excitation. Engineering Structure, 29 (21), 2833 2843.

Dinas Pekerjaan Umum (1992). Bridge Management System (BMS). Jakarta: Dinas Pekerjaan Umum.

El-Dardiry, E. (2003) Floor Vibration Induced by Walking Loads. PhD Thesis. University Of Manchester.

Ellis, B.R., Ji, T. (2003). Load Generated by Jumping Crowds : Numerical Modelling. The Structural Engineer, 81(6), 20-27.

Litter, J. D. (2003) Frequencies of Synchronized Human Loading from Jumping and Stamping. IStrucE: The Structural Engineer, 81(11), 27-35.

Wahyuni, E. (2012) Studi Kelakuan Dinamis Struktur Jembatan Penyeberangan Orang Akibat Beban Individual Manusia Bergerak. Jurnal Teknik Sipil ITS, Vol. 19 No. 3 Desember 2012. 